\title{
Nursing now: commitment of nursing at the "Dr. Manuel gea gonzález" general hospital
}

Keywords: parliamentary group, stakeholders, nursing now, triple impact, care management

Abbreviations: WHO, world health organization; ICN, international council of nurses

\section{Introduction}

The objective of this article is to inform on the implementation of the local group "Nursing Now"-Enfermería Gea, as one constituent of the "Nursing Now"-SSA Mexico national system, who aims at supporting the "Nursing Now" Global Campaign being promoted by the International Council of Nurses (ICN) and the World Health Organization (WHO).

\section{The "nursing now" world campaign}

The backgrounds of the "Nursing Now" campaign date back to September 2015, when the Global Health All-Party Parliamentary Group of the United Kingdom ${ }^{1}$ released a report highlighting the need to strengthen the profession of Nursing worldwide in order to guarantee the provision of healthcare to all persons in the world. This Group is integrated by personalities from areas of the economy, research, politics, etcetera - which include main leaders of the UK Parliament such as Dan Poolter, Lord Darzi, Lord Crisp, Meg Hillier, Norman Camb, Lord Ribeiro, Lord Kakkar and the Baroness of Northover, ${ }^{2}$ among others. The Group is also supported by important academic institutions such as The Lancet and the Bill and Melinda Gates Foundation.

\section{“Triple impact”of nursing}

In its inform, the Global Health All-Party Parliamentary Group of the United Kingdom concluded that strengthening nursing worldwide would have a global health "Triple Impact" resulting from the alliances with main stakeholders to support nurses to lead, learn, and utilize all their potential for the benefit of the communities. ${ }^{3}$

Based on the projections of the Global Health All-Party Parliamentary Group of the United Kingdom - including that of the nursing "Triple Impact" - the International Council of Nurses (ICN) ${ }^{4}$ and the World Health Organization (WHO) implemented the 3-year Global Campaign (2018-2020) "Nursing Now" to strengthen nursing worldwide and improve global healthcare and gender equality, and thus the world economies.

\section{"Nursing now" campaign - Mexico}

On November the 29th, 2017, the National Direction of Nursing of the Health Secretariat of Mexico joined "Nursing Now". This campaign was further informed during the 2nd Nursing National Meeting 2018 in order to replicate it within Local Groups.

i. An important concern is to promote that at least $75 \%$ of the medical units in Mexico become aware of "Nursing Now" and the parallel potential of nursing. ${ }^{5}$ In line with the general objectives, the strategic goals are:

ii. To promote in nursing leaders the acquisition of the leadership and
Volume 4 Issue 5 - 2019

\author{
Wendy Melina Suasto Gómez,' Lasty \\ Balseiro Almario, ${ }^{2}$ Irma Jiménez Escobar, ${ }^{3}$ \\ Ana Lilia Hernández Hernández, ${ }^{4}$ María \\ Adriana Chaparro Sánchez, ${ }^{5}$ Aylín Maylén \\ Rosas Rodríguez, ${ }^{6}$ Alexis Omar Guzmán \\ Trejo ${ }^{6}$ \\ 'Nursing Sub-Director of the "Dr. Manuel Gea González" \\ General Hospital, Mexico \\ ${ }^{2}$ Senior Career Professor "B" at the National School of Nursing \\ and Obstetrics, National Autonomous University of Mexico, \\ Mexico \\ 3Medical Director at the "Dr. Manuel Gea González" General \\ Hospital, Mexico \\ ${ }^{4}$ Chief of the Nursing Clínical Areas at the "Dr. Manuel Gea \\ González" General Hospital, Mexico \\ ${ }^{5}$ Chief of the Nursing Teaching and Research Department at the \\ “Dr. Manuel Gea González" General Hospital, Mexico \\ ${ }^{6}$ Nursing Bachelor's Degree Residents at the National School \\ of Nursing and Obstetrics, National Autonomous University of \\ Mexico, Mexico
}

Correspondence: Lasty Balseiro Almario, Senior Career Professor "B" at the National School of Nursing and Obstetrics, National Autonomous University of Mexico, Mexico, Email lastybals@hotmail.com

Received: October 09, 2019 | Published: October 15, 2019

management skills to improve the provision of health services, making sure that $100 \%$ of the Nursing State Commissions are visible through the official broadcasting media.

iii. To promote the implementation of Advanced Practice Nursing with a focus on primary care to the populations in conditions of margination.

iv. To constitute a proposal document about the trends and projections of nursing towards 2030 in order to address the changing health needs of the country. ${ }^{6}$

\section{“Nursing now"-enfermería gea}

The Nursing Sub-Direction of the "Dr. Manuel Gea González" General Hospital began embracing the "Nursing Now" initiative carrying out a SWOT analysis considering:

\section{Care management-gea}

This initiative includes an analysis of areas of opportunity for nurses in order to assess their leadership and management knowledge, skills, and abilities to perform through diverse patient-beneficiary roles. Among the related care management strategies are:

1. To create the Direction of Nursing instead of the present Nursing Sub-Direction;

2. To strengthen the institutional leadership among nursing chiefs and supervisors; 
3. To promote the Nursing Care Management Model among staff;

4. To promote the nursing philosophy of Mission, Vision, and Values.

\section{Clinical services-gea}

This initiative focuses on the Hospital's clinical areas where nurses provide care through different models and technologies related to primary, secondary, and tertiary care. Among the clinical services strategies are:

a. To enhance nursing capacity by ensuring the necessary supplies to provide patient care;

b. To begin the publication of scientific articles related to the clinical tasks which nursing staff perform

c. To begin and complete the research on the intelligent infusion bombs;

d. To assess the activities carried out by the nursing supervisors at the Hospital.

\section{Teaching and research-gea}

This initiative includes strengthening the institutional leadership areas to promote the development of nurses in the present and future. ${ }^{7}$ Among the teaching and research strategies are:

i. To carry out an assessment on the professional and not professional staff training needs through specific surveys;

ii. To begin the process of Nursing Professional Certification;

iii. To strengthen the Advanced Practice Nursing at all levels;

iv. To offer a "short path" graduation option to all specialists who are lagging in the education schedule;

v. To create a Leadership and Human Development Diploma program for the nursing chief and supervision staff.

\section{Main objectives of "nursing now"-enfermería gea}

The main objectives for these three years include the strengthening of the Care Management, Clinical Services, and Teaching and Research initiatives, while simultaneously supporting the Campaign's "Triple Impact" by promoting the leadership and empowerment of all nurses in the hospital through innovative nursing care models with a special focus on primary care.

\section{Members of the local group}

\section{Executives}

Wendy Melina Suasto Gómez; MsD, Nursing Sub-Director of the "Dr. Manuel Gea González" General Hospital; Ana Lilia Hernández Hernández; MsD Chief of the Nursing Clínical Areas at the "Dr.
Manuel Gea González" General Hospital, María Adriana Chaparro Sánchez; MsD Chief of the Teaching and Research Department; Evelia Jacobo Marín, MsD and Vianey Benítez Martínez, BsD, Chiefs of the Service.

\section{Nursing residents}

Aylín Maylén Rosas Rodríguez, Diana Laura Martínez Felipe, Ana Karen Gudiño Guzmán, Alexis Omar Guzmán Trejo y Luis Adrián Vázquez Rodríguez.

The 12th of May, International Nursing Day, has been chosen for the commemoration of the "Nursing Now" - Enfermería Gea project provided the corresponding acknowledgement of other related institutional authorities including the Hospital's Medical Direction and General Direction.

\section{Conclusion}

Acknowledged by the Health Secretariat, in the general, and by the Nursing Permanent Commission, in the particular, "Nursing Now" Mexico is a proposal to improve the capabilities and potentials of nurses to enhance quality patient healthcare to all persons in Mexico, and thus contribute to the advancement of the economy. This way, nurses in all Mexico will become team leaders coordinating and managing the health services for all, but mainly for the most vulnerable populations. Because of this, Nursing at the "Dr. Manuel Gea González General Hospital takes the challenge and decides to adopt and begin its part in the global initiative as "Nursing Now" Enfermería Gea for the next 3 years.

\section{Acknowledgement}

None.

\section{Conflicts of interest}

The authors declare that there is no conflict of interest.

\section{References}

1. https://www.who.int/hrh/com-heeg/digital-APPG_triple-impact.pdf?ua=1

2. http://www.cpe.salud.gob.mx/site3/programa/docs/presentacion_nursing_ now.pdf

3. http://www.cpe.salud.gob.mx/site3/programa/docs/presentacion_nursing _ now.pdf

4. http://www.cpe.salud.gob.mx/site3/programa/docs/presentacion_nursing_ now.pdf

5. http://www.cpe.salud.gob.mx/site3/programa/nursing_now_mexico.html

6. http://www.cpe.salud.gob.mx/site3/programa/nursing_now_mexico.html

7. Suasto WM. Project: creation and puesta on the march field: nursing now - nursing gea. Dr. Manuel Gea González general hospital. México; 2019:9. 